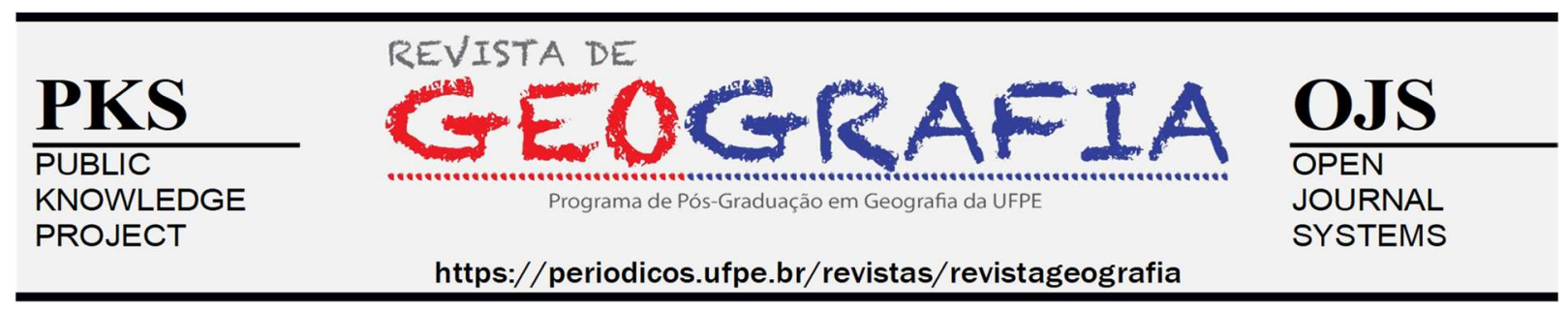

\title{
COMPORTAMENTO GEOMORFOLÓGICO DE VOÇOROCA NO MUNICÍPIO DE TUCANO - SEMIÁRIDO BAIANO
}

\author{
Bismarque Lopes Pintoํㅡㄹ Hélio Mário de Araújo ${ }^{2}$ \\ ${ }^{1}$ Universidade Federal de Sergipe (UFS), Programa de Pós-Graduação em Geografia (PPGEO). E-mail: \\ bismarque.lopes93@gmail.com \\ 2 Universidade Federal de Sergipe (UFS), Programa de Pós-Graduação em Geografia (PPGEO). E-mail: \\ heliomarioaraujo@yahoo.com.br
}

Artigo recebido em 16/02/2020 e aceito em 31/05/2020

\begin{abstract}
RESUMO: Abordar o tema voçoroca e erosão dos solos é de fundamental importância para se compreender como esse fenômeno influencia na evolução das paisagens, já que os as atuais cicatrizes erosivas na paisagem dão subsídios para uma melhor compreensão da dinâmica do ambiente natural pretérito e atual de modo que o seu comportamento geomorfológico denuncia a atuação dos condicionantes ambientais na esculturação do relevo. Nesse sentido, objetivou-se nesta pesquisa analisar o comportamento geomorfológico de uma voçoroca, bem como o desenvolvimento de morfologias internas e o posicionamento tipológico sobre a vertente na zona rural do município de Tucano, semiárido baiano. Os procedimentos metodológicos, foram pautadas metodologias específicas que levaram ao reconhecimento morfológico da feição erosiva. A pesquisa foi realizada nas etapas de pré-campo no levantamento teórico e cartográfico preliminar, também houve a realização dos perfis topográficos, além do trabalho de campo com a aplicação de metodologias de classificação da voçoroca e feições associadas, finalizando com a etapa de pós-campo que se com a tabulação e análise dos dados qualitativos obtidos em campo. Constatou-se que a voçoroca apresenta dimensões em torno de $13,377 \mathrm{~km}^{2}$, com aspecto morfológico ramificado, constituído de 04 canais secundários e padrão desconectado da rede de drenagem local.
\end{abstract}

Palavras-chave: comportamento geomorfológico, erosão, voçoroca.

\section{GEOMORPHOLOGICAL BEHAVIOR OF A YOUNG IN THE MUNICIPALITY OF TUCANO - BAHIAN SEMIARID}

\begin{abstract}
Addressing the theme of soil development and erosion is of fundamental importance to understand how this phenomenon influences the evolution of landscapes, since the evolutionary and current understandings of erosive scars in the landscape provide support for a better understanding of the dynamics of the past and present natural environment, so that its geomorphological behavior denounces the environmental constraints in its relief carving process. The objective of this study was to analyze the geomorphological behavior of a young people as well as the development of internal morphologies and typological positioning on the strand in the rural area of the municipality of Tucano Bahia semiarid. Regarding the methodological procedures, specific methodologies were guided that led to the morphological and Morphometric recognition of the erosive features, so the research was performed in the prefield in the preliminary theoretical and cartographic survey as well as in the accomplishment of the topographic profiles, the field work with the application of methodologies for classification of the group and associated features, ending with the post-field of tabulation and analysis of quantitative and qualitative data obtained in the field. As a result, the group presents dimensions around $13.377 \mathrm{~km}^{2}$, with branched morphological aspect, consisting of 04 secondary channels and standard disconnected from the local drainage network.
\end{abstract}

Keywords: geomorphological behavior, erosion, gully. 


\section{INTRODUÇÃO}

A erosão é um dos fenômenos ambientais mais evidentes na paisagem, pois é com a erosão, que o sistema natural começa a desequilibrar-se, alimentando sucessivas fases de deterioração dos demais elementos ambientais para que, por fim, se possa recriar um novo cenário paisagístico. Dessa forma, o desenvolvimento de voçorocas no ambiente se constitui como um fenômeno de desequilíbrio da paisagem. Logo, para compreender tal fenômeno, é necessário entender o ambiente como uma cadeia sistêmica sujeita a mudanças em seu estado de "equilíbrio" a todo momento.

As chuvas torrenciais, frequentemente observadas em ambiente semiárido, concentramse em alguns meses do ano. Esse modelo de precipitação se constitui como um fator agressivo ao solo por conta de sua intensidade energética destinada a precipitação, pois além do volume das gotas tem-se o fator intensidade que não permite que os horizontes do solo escoem naturalmente, causando o escoamento superficial (figura 08). O impacto direto da chuva, causa o destacamento das partículas do devido à energia que foi colocada naquela ação, causando a erosão por "splash" (CARVALHO et. al, 2006).

A frequência dos eventos chuvosos pode induzir negativamente as perdas de solo. Nesse sentido, quanto maior for o tempo de intervalo entre os eventos chuvosos, melhor será para o solo que terá tempo para escoar, tendo em vista que, quando o solo está encharcado e ocorre outra chuva torrencial, a cobertura pedológica perde a sua capacidade de infiltração por conta da saturação, e com isso começa-se a gerar o escoamento superficial, dando início a erosão (BERTONI e LOMBARDI NETO, 2010).

Nesse contexto, as oscilações climáticas e atividades tectônicas estabeleceram na paisagem processos de reestruturação geomorfológica, que vêm sendo retrabalhados até os dias atuais através dos sistemas de voçorocamento que esculpem a modelagem terrestre provocando modificações no padrão de vertente, rebaixamento do relevo, bem como formação de extensos depósitos coluvionais (MELLO, 1997).

Já Ross (1992), em sua pesquisa taxonômica de classificação do relevo, ressalta as feições erosivas destacando a voçoroca, como o $6^{\circ}$ táxon de classe do relevo, correspondendo às feições geradas pelos processos morfodinâmicos atuais, influenciado tanto pelos condicionantes ambientais como pelas intervenções antropogênicas no ambiente. Neste sentido, os estudos de voçorocas enquadram-se na proposta de Ross (1992) quando busca-se analisar os processos 
morfogenéticos que envolvem a evolução do relevo local associados às modificações realizadas ao longo da vertente.

Assim, em solos onde possuem desequilíbrios em sua estrutura físico-química, há a presença de pináculos no fundo ou nas laterais das feições de voçorocas. Dessa forma, a feição de pináculo está associada à formação de “[...] sulcos verticais profundos nas voçorocas. Uma camada de solo resistente, ou cascalhos e pedras, muitas vezes encabeçam a parte superior dos pináculos [...]” (BERTONI e LOMBARDI NETO, 2010, p. 78). Ainda nas paredes das voçorocas, pode-se encontrar a formação de escamamentos que são resultados do "[...] acúmulo de material fino (areia fina ou muito fina) sobre superfície mais resistente [...]” (VIEIRA, 2008, p. 61).

Dada a constituição da voçoroca na vertente, outras feições acabam se agrupando ao processo erosivo. Dessa maneira, as formações de pedestais são características de ambientes erosivos, pois sua formação se dá quando há o processo inicial de erosão por salpicamento e todos os materiais das laterais são removidos pelo escoamento laminar, deixando de forma isolada, torrões de solos isolados que resistiram ao efeito inicial do splash e do carregamento laminar (BERTONI e LOMBARDI NETO, 2010).

Inclusive, as formações de pedestais (BERTONI e LOMBARDI NETO, 2010) são características de ambientes erosivos, afinal sua formação se dá quando há o processo inicial de erosão por salpicamento e todos os materiais das laterais são removidos pelo escoamento laminar, deixando, torrões de solos isolados que resistiram ao efeito inicial do splash e do carregamento laminar (BERTONI e LOMBARDI NETO, 2010).

Com isso, cabe ressaltar na perspectiva de Guerra (2011) que o desenvolvimento da erosão na paisagem não deve ser entendido apenas como um fator antropogênico, mas sim, sob o ponto de vista dos condicionantes da estrutura pedológica da dinâmica da vertente local como da dinâmica pluviométrica da área. Então, todos esses fatores tornam-se indicadores para a compreensão dos mecanismos de formação de uma voçoroca.

Cada erosão possui suas particularidades em sua formação e desenvolvimento. Dessa forma, tal fenômeno deve ser entendido a partir de diversos fatores que influenciam em sua geração. Desse modo, buscando uma análise holística do ambiente erosivo, objetivou-se analisar o comportamento geomorfológico de uma voçoroca, além do desenvolvimento de morfologias internas e posicionamento tipológico sobre a vertente na zona rural do município de Tucano, semiárido baiano. 


\section{ÁREA DE ESTUDO}

A voçoroca (figura 1) em estudo abrange uma área de 13,377 km² e localiza-se a $10^{\circ} 57^{\prime} 10^{\prime \prime}$

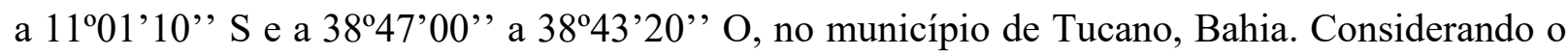
tipo climático predominante da área num contexto de transição do clima semiárido para o subúmido a seco, verifica-se que a ocorrência de precipitações médias anuais varia de 600 a 700 $\mathrm{mm}$.

Figura 1 - Voçoroca, Tucano/BA, 2018.

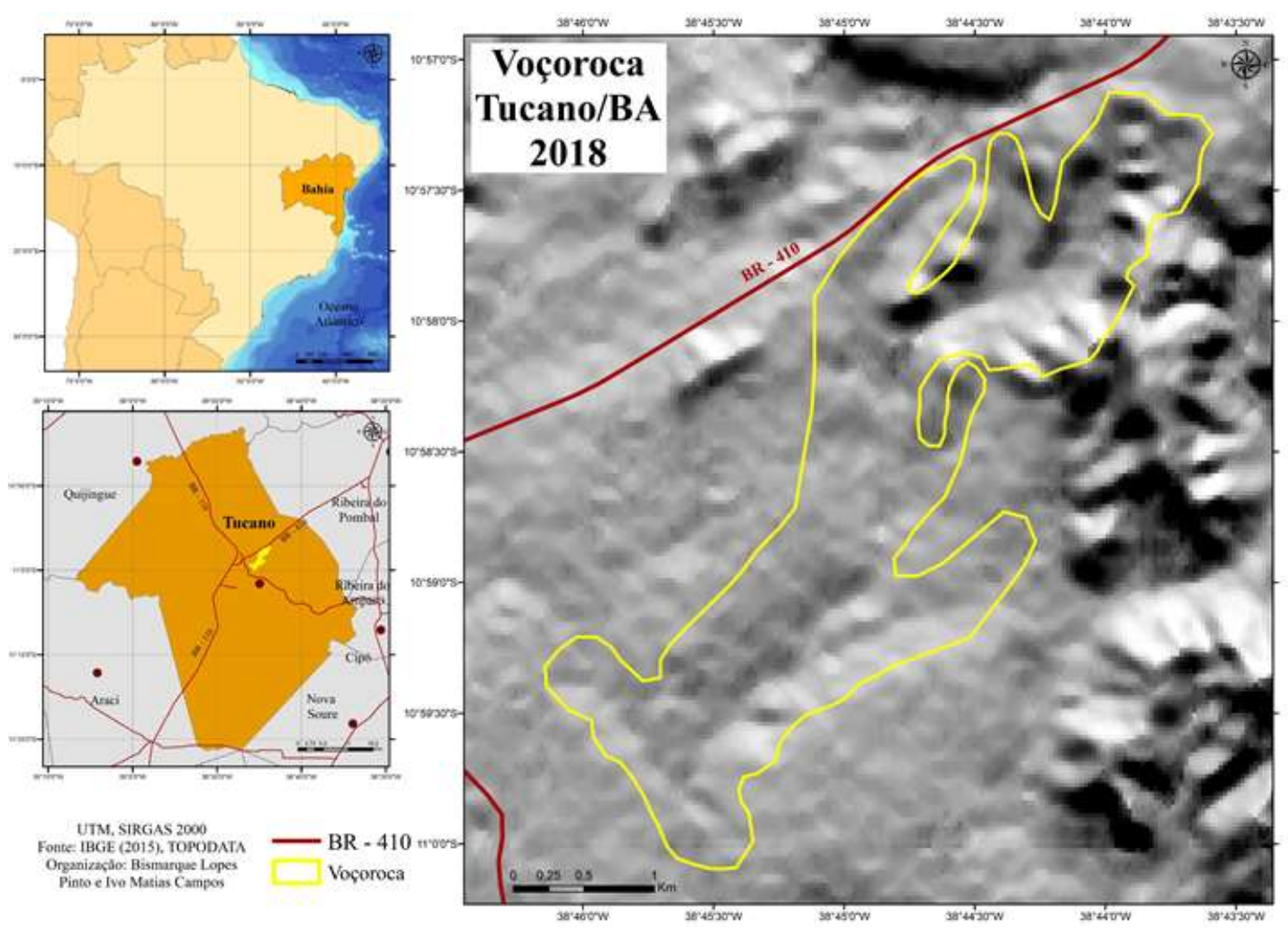

Fonte: Os autores, 2018.

Nesse contexto, percebe-se que a dinâmica pluviométrica local pode ser entendida como o input inicial do sistema de voçorocamento, uma vez que, corroborando com Bertalanffy (1977), as chuvas torrenciais concentradas em alguns meses do ano, funcionam como a energia cinética inicial que impulsiona o aparecimento do efeito splash sobre a camada pedológica bem como dando início ao escoamento superficial concentrado, permitindo a entrada de um volume de energia significativa no sistema, além de movimentar a matéria pedológica até a zona de dejeção (output) do sistema de voçoroca. 


\section{METODOLOGIA}

\section{Confecção do mapa de Altimetria e Declividade}

Os dados de altimetria e declividade foram extraídos das grades TIN, construídas a partir das imagens 10S39_ZN e 11S39_ZN do projeto TOPODATA da SRTM, refinada pelo método Krigagem, em que a resolução de 90 metros é aumentada para 30 metros. O projeto TOPODATA foi desenvolvido pelo INPE e disponibilizado pela EMBRAPA por monitoramento de satélites. No mapa de altimetria da voçoroca, optou-se pela quebra de curva de nível de 50 a 50 metros por cota altimétrica.

\section{Classificação do modelo de vertente sob as feições erosivas}

Para uma melhor compreensão da dinâmica e comportamento da voçoroca analisada, fez-se um reconhecimento prévio do modelo de vertente sob a cicatriz erosiva a partir do modelo de Ruhe (1975). Segundo o autor, as vertentes podem ser classificadas em retilínea (r), Convexa (cx) ou Côncava (cc). Na própria classificação, o autor associa que em uma mesma vertente, formas diferentes de composição entre o terço superior com o terço médio e inferior.

\section{Classificação da morfologia externa e interna das voçorocas}

Através do programa ArcGis 10.1, foram utilizadas as imagens 10S39_ZN e 11S39_ZN do projeto TOPODATA da SRTM para a delimitação e classificação prévia da morfologia externa da voçoroca. Assim, como forma de validação, fez-se a atividade de campo para o reconhecimento dos canais secundários e a dimensão total da voçoroca.

As representações morfológicas externas classificadas por Bigarella e Mazuchowski (1985), estão associadas ao padrão de escoamento superficial concentrado. Nas feições lineares, o escoamento forma apenas um fluxo e incisão única, a bifurcada tem dois pontos de incisão através do fluxo concentrado, já as feições ramificada e irregular apresentam diversos fluxos concentrados que convergem em uma única abertura do solo. A feição retangular é a representação evolutiva final das demais feições apresentadas.

Neste mesmo processo de classificação morfológica externa fez-se a setorização das voçorocas em terço superior (setor de erosão) e terço inferior (setor de acumulação). Logo, como critério para a setorização, realizou-se a atividade de campo associada à leitura dos dados morfométricos (comprimento, largura e profundidade dos canais) para classificar a área de predominância erosiva e a área de acúmulo de sedimentos. 
Dentro deste contexto, é importante destacar que o reconhecimento e classificação das morfologias internas da voçoroca se deram exclusivamente através da atividade de campo, a partir da leitura prévia das abordagens conceituais existentes sobre a descrição de possíveis morfologias já diagnosticadas em sistemas erosivos. Assim, as morfologias internas identificadas em campo foram fotografadas, descritas no diário de bordo e registradas sua localização a partir do aparelho GPS.

\section{Classificação Tipológica}

A partir do mapa altimétrico, foi traçado um perfil longitudinal da vertente para observar previamente a situação da voçoroca sobre a mesma, para assim, analisar seu posicionamento topográfico. Para a classificação da tipologia erosiva, embasou-se nos estudos de Oliveira (2009) visando determinar a tipologia de uma voçoroca em formato conectado, desconectado e integrado, que dependerá da localização da mesma na vertente, uma vez que, se a voçoroca estiver ligada a rede de drenagem ela é conectada, mas se a voçoroca estiver formada no topo da vertente ela será desconectada. Nesse sentido, tendo em vista que a voçoroca já toma toda a vertente, fazendo a ligação entre topo e a base (ou ligação com a rede de drenagem), percebe-se que ela constitui na tipologia integrada.

Para a validação da classificação feita pré-campo, realizou-se atividade de campo na área da voçoroca nos quais foram feitos registros fotográficos, diário de bordo e marcação de ponto através do aparelho GPS, de modo a validar o posicionamento longitudinal das voçorocas sobre a vertente e determinar sua tipologia.

\section{RESULTADOS E DISCUSSÕES}

Declividade e variações altimétricas

O município de Tucano está inserido no domínio do semiárido brasileiro, cujo clima, se caracteriza pela escassez pluviométrica ao longo do ano, apresentando médias que atingem índices aproximados dos $800 \mathrm{~mm}$. Em 2010, por exemplo, os valores de chuvas registrados corresponderam ao total máximo de $792 \mathrm{~mm}$, enquanto em 2012, as precipitações não ultrapassaram os $306 \mathrm{~mm}$ anuais. Essa situação se configura na escala mensal, onde as variações estão associadas não somente a organização natural do ambiente de semiaridez, mas também pelas sucessivas fases de seca habituais na região que promovem meses de estiagem com índices 
inferiores a $10 \mathrm{~mm}$, e períodos de chuvas torrenciais de até $154 \mathrm{~mm}$, principalmente nos meses de abril, maio e julho.

Essa rigorosidade climática, sem dúvida, repercute no ritmo de evolução morfológica da voçoroca em análise, associados a outros aspectos naturais do estrato geográfico da área onde está inserida. A referida voçoroca apresenta dimensões aproximadas de $13,311 \mathrm{Km}^{2}$, e sua dinâmica erosiva está associada ao modelado da encosta que exibe perfil convexo-côncavo (RUHE, 1975), apresentando aspecto morfológico de topo convexo, com o reajuste por achatamento pela atuação dos processos erosivos pretéritos associados a forte declividade de quebras abruptas de altimetria para transição ao segmento côncavo.

O terço médio e inferior da vertente, possui uma forma retilínea em formato de rampa, típico de vertente recoberta por camadas de sedimentos erodidas por processos anteriores de desgastes naturais resultantes da evolução dos tabuleiros, formando, por consequências, extensos cones de dejeção. Dessa maneira, o formato de rampa estabelece uma conexão com as superfícies aplainadas que são generalizadas entre as formas tabuliformes. O modelo convexo-côncavo exibido na vertente influencia no aceleramento do fluxo das águas pluviais, possibilitando a formação de sulcos e ravinas. As cotas altimétricas mais elevadas entre 332 a 430 metros, localizam-se no topo da voçoroca (figura 2).

Figura 2 - Mapa de altimetria e declividade da área da Voçoroca em Tucano/BA, 2018.

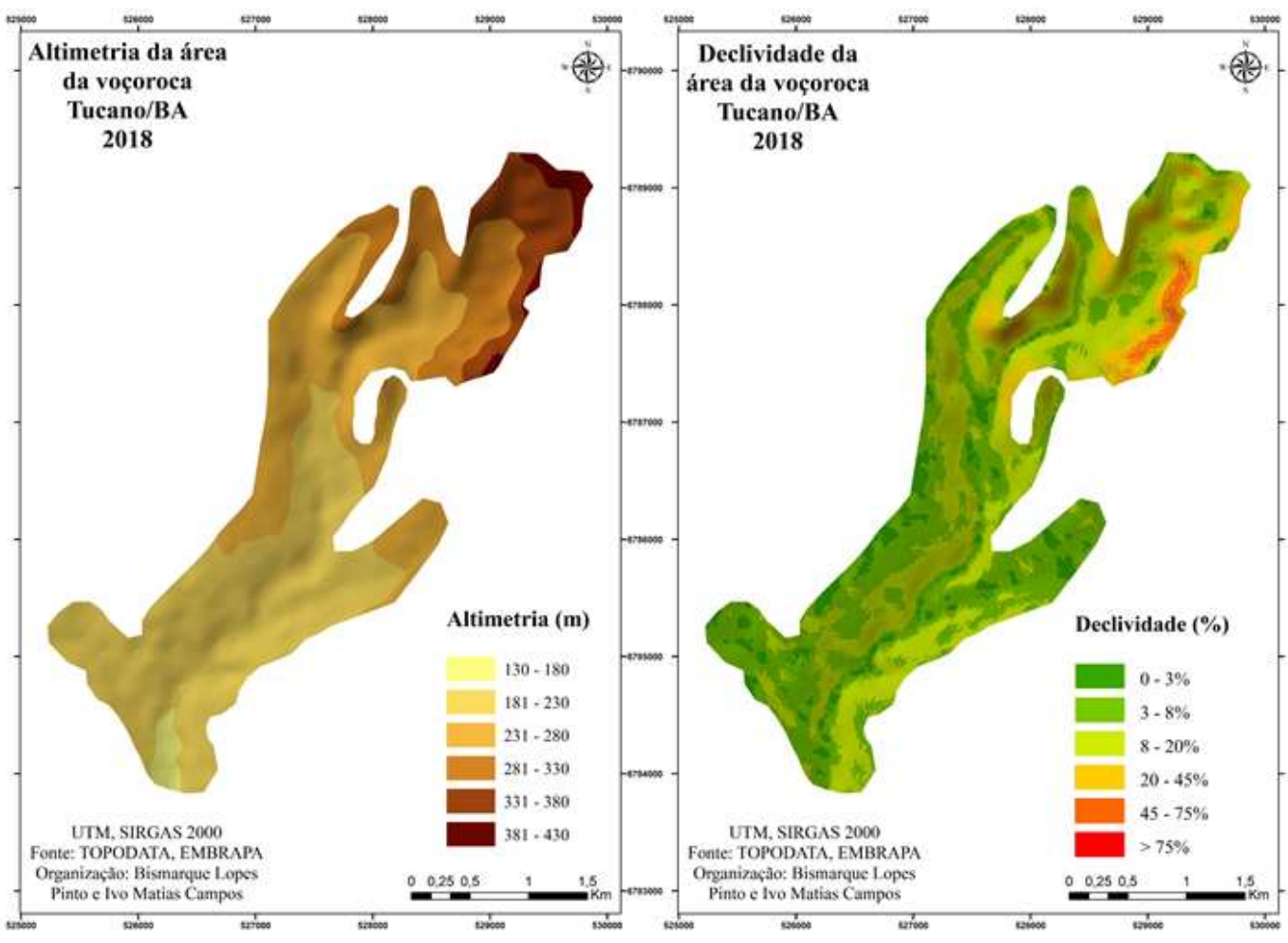

Fonte: Os autores, 2018. 
Nesses níveis altimétricos, a cabeceira da voçoroca assenta-se sobre o topo do tabuleiro, sendo constantemente retrabalhadas por processos de ravinamento que se disseminam na porção superior, formando, assim, uma estrutura íngreme, com declividades de $20-45 \%$ a $45^{\circ}-75 \%$ (figura 3). Seguindo as proposições de Ross (2010), em tais níveis, predominam feições convexas e com níveis superiores a 30\% de declividade, apresentando morfologias aguçadas e com forte entalhamento.

Figura 3 - Processo de ravinamento na cabeceira do canal principal da voçoroca a 330 metros de altitude entre 45 a $75 \%$ de inclinação.

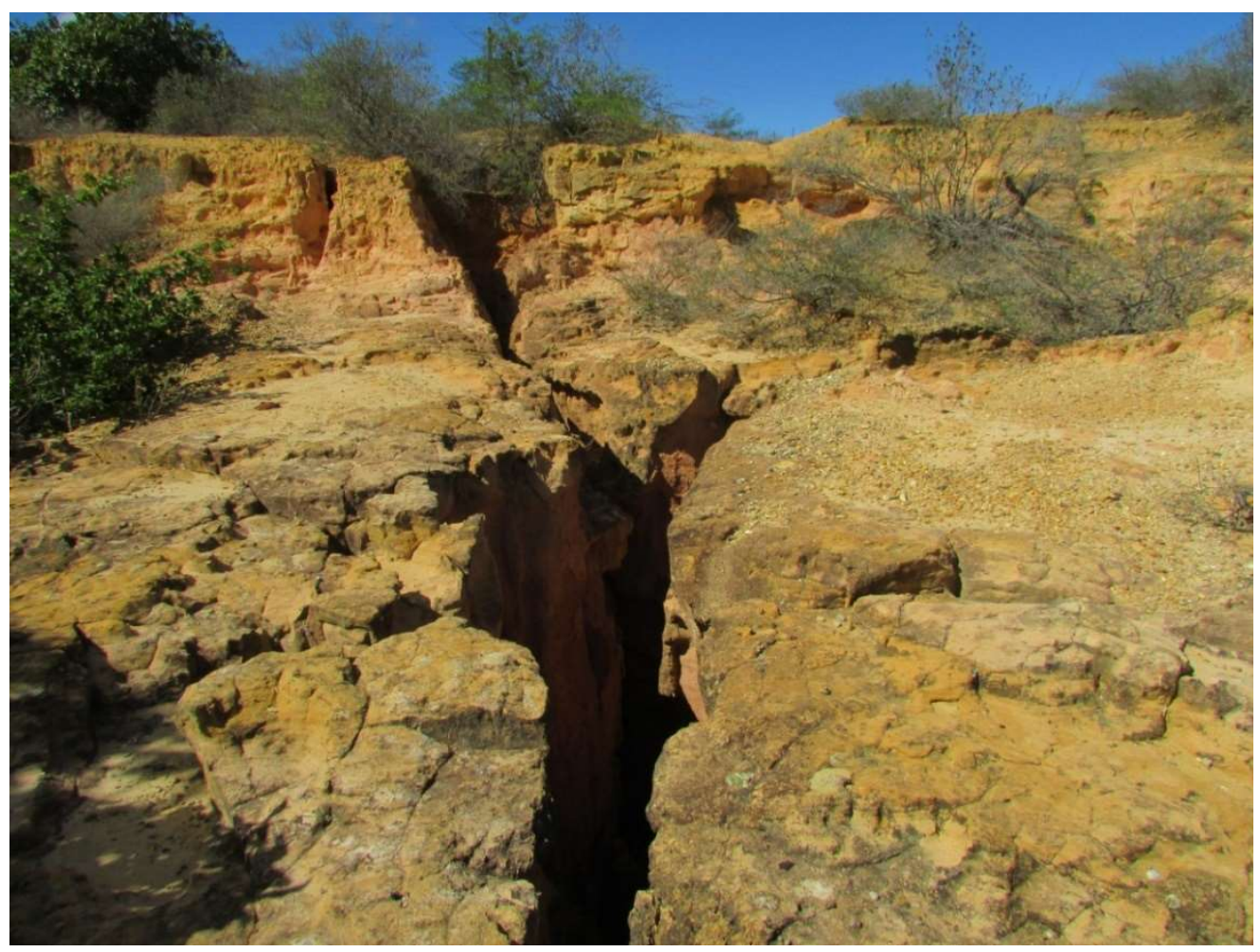

Fonte: Acervo particular dos autores, 2018.

As cotas altimétricas e planos de declividade apontados acima (figura 02) corroboram com a perspectiva de Lepsch (2002) e Bertoni e Lombardi Neto (2010) ao aponta que nesses gradientes de inclinação superiores a $30 \%$, a própria vertente induz naturalmente ao processo erosivo, favorecendo ao escoamento superficial concentrado que ganha maior energia por conta da modelagem da vertente.

Para Braun (1961), encostas com predomínio de formas convexas ou côncavas aumentará significativamente a chances de erosão em lençol e mais rapidamente a erosão por fluxos superficiais concentrados, desenvolvendo assim, sulcos, ravinas e voçorocas. De acordo com Guerra (2011) a atribuição conjunta de planos altimétricos elevados com modelagens íngremes 
de encosta se constituem fatores essenciais para o rompimento acelerado da camada superficial do solo por efeito splash e posteriormente, este material retirado é induzido ao transporte pela energia cinética da água que ganha força pela descida natural da vertente, fazendo evoluir o fluxo superficial concentrado.

O segundo setor de abrangência altimétrica no interior da voçoroca situa-se entre 231 a 280 metros de altitude. Nesse intervalo de classe, se encontra a área de maior abertura do canal principal, apresentando uma variação em torno de $3 \%$ a $20 \%$ de inclinação, formando assim, uma área aberta com maior rebaixamento (figura 4). Nesse segmento, Ross (2010) sugere uma dissecação de pouca intensidade, resultante de diversos processos erosivos anteriores que já retrabalharam a área.

Figura 4 - Segmentos da dimensão espacial do canal principal da voçoroca 01.

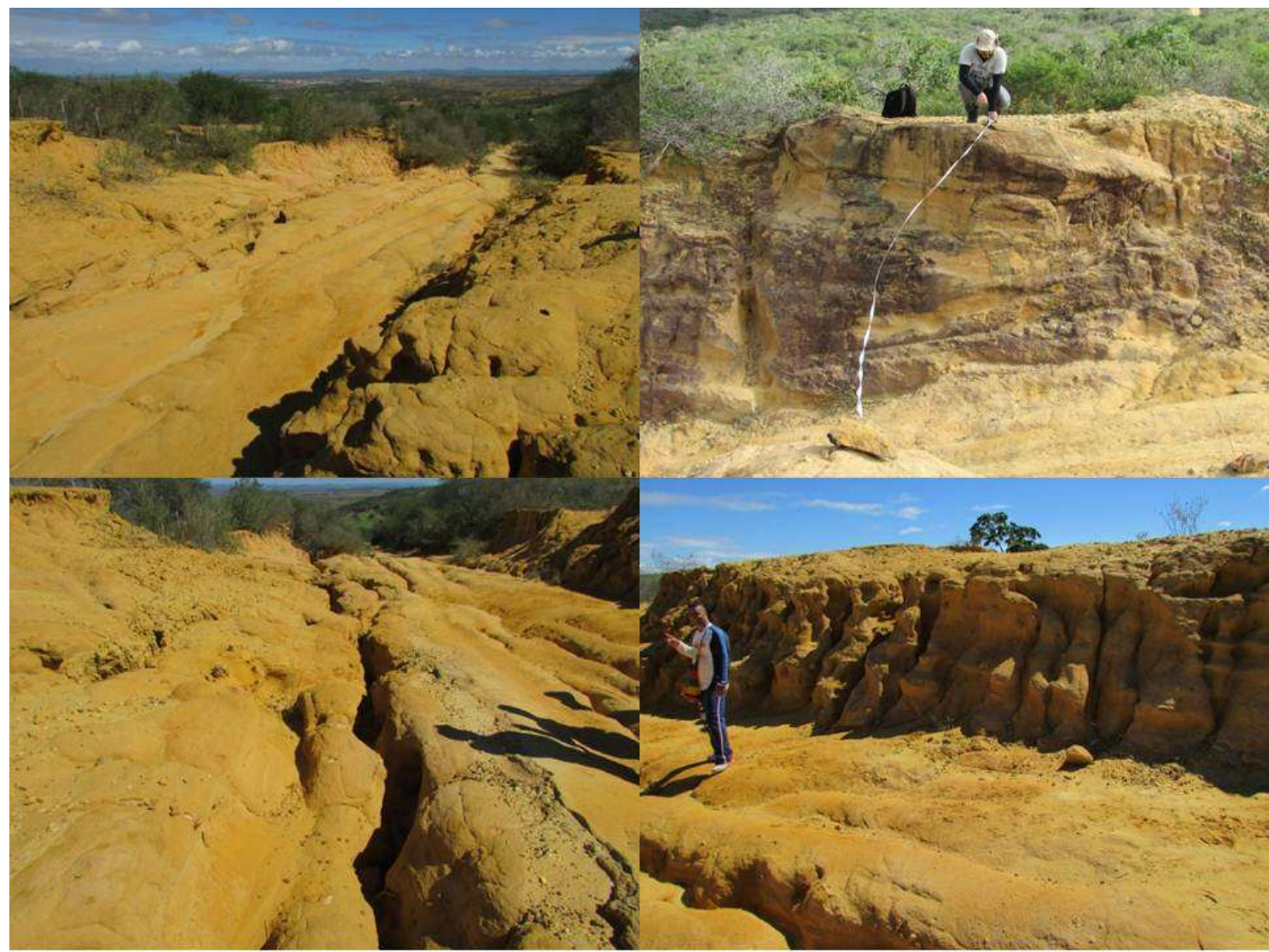

Fonte: Acervo particular dos autores, 2018.

No setor inferior da voçoroca, encontra-se uma altimetria suavizada com variação de 130 a 230 metros, intercalados com planos de declividade entre $0^{\circ}$ a $3^{\circ}$. Neste intervalo de classe, verifica-se a predominância de parte do material coluvional proveniente dos níveis altimétricos 
mais elevados da voçoroca, formando cones de dejeção, que segundo Ross (2010) o próprio nível de declividade já indica uma dissecação fraca com superfícies planas.

Organização morfológica externa e interna

A organização morfológica da voçoroca é uma resposta do processo evolutivo pretérito, associado às feições que ali foram modeladas de acordo com a dinâmica erosiva do sistema de degradação na vertente. Dessa maneira, as variações externas e internas das morfologias existentes se constituem parâmetros base para a identificação do grau evolutivo da voçoroca e sua consequente perda de solo.

A partir disso, de acordo com os parâmetros estabelecidos por Bigarella e Mazuchowski (1985), a voçoroca apresenta uma morfologia ramificada, com diversos fluxos irregulares que levam ao escoamento de um único fluxo principal (figura 5). Dessa forma, essa voçoroca apresenta 04 (quatro) canais secundários e um canal principal. Inclusive, dois canais secundários localizam-se em seu terço superior, enquanto os outros dois no terço inferior.

Figura 5 - Configuração morfológica externa e setorização das unidades de erosão e acumulação da voçoroca em Tucano/BA, 2018.

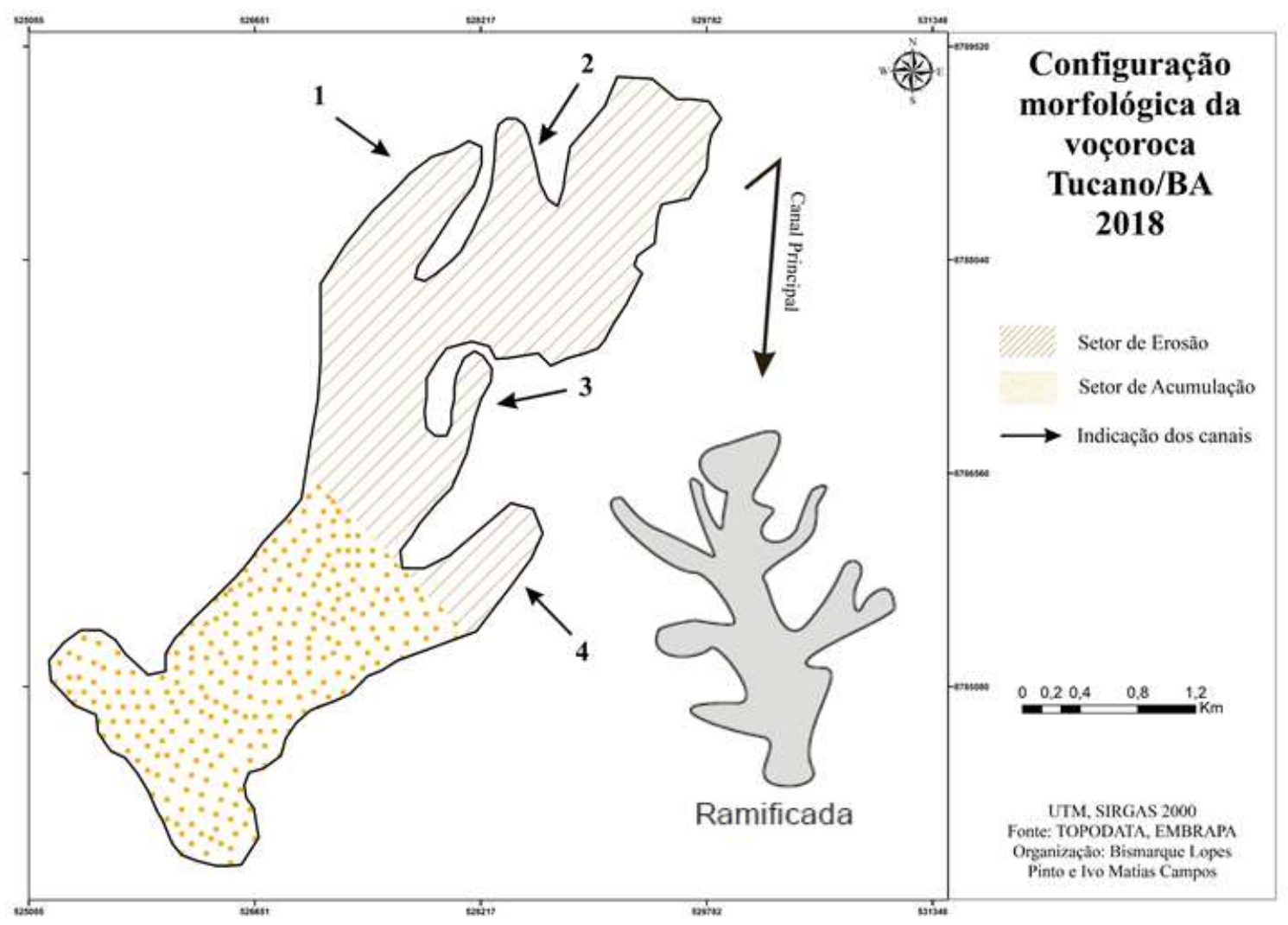

Fonte: Os autores, 2018. 
De acordo com Vieira (2008), o predomínio da forma ramificada denuncia uma evolução em média escala do processo erosivo, tendo em vista que já não há apenas um ou dois fluxos superficiais concentrados, mas sim, diversos fluxos que convergem em um único canal de recebimento de toda essa carga de matéria transportada pelas águas pluviais. A feição ramificada geralmente é encontrada em vertentes na qual já se encontra níveis consideráveis de rebaixamento, possivelmente provocados pela atividade erosiva em suas formas antigas (linear ou ramificada).

Com isso, levando-se em consideração os níveis altimétricos do relevo, divide-se a área que envolve a voçoroca em dois terços. O terço superior corresponde a $9,12 \mathrm{~km}^{2}$ da área com predomínio de atuação dos processos erosivos, sem a formação de bancos de sedimentos (figuras $6 \mathrm{a} / \mathrm{b}$ ); e o terço inferior corresponde a $4,24 \mathrm{~km}^{2}$ da área considerada de sedimentação, por não apresentar nenhum canal secundário com forte atuação erosiva, mesmo apresentando sucessivos cones de dejeção, oriundos de transporte do material erodido do terço superior.

Figura 6 - a) Processos erosivos no canal secundário 01, apresentando incisão vertical de 15,36 metros; b - Complexo erosivo no canal secundário 03 , com incisão vertical de 10,23 metros.

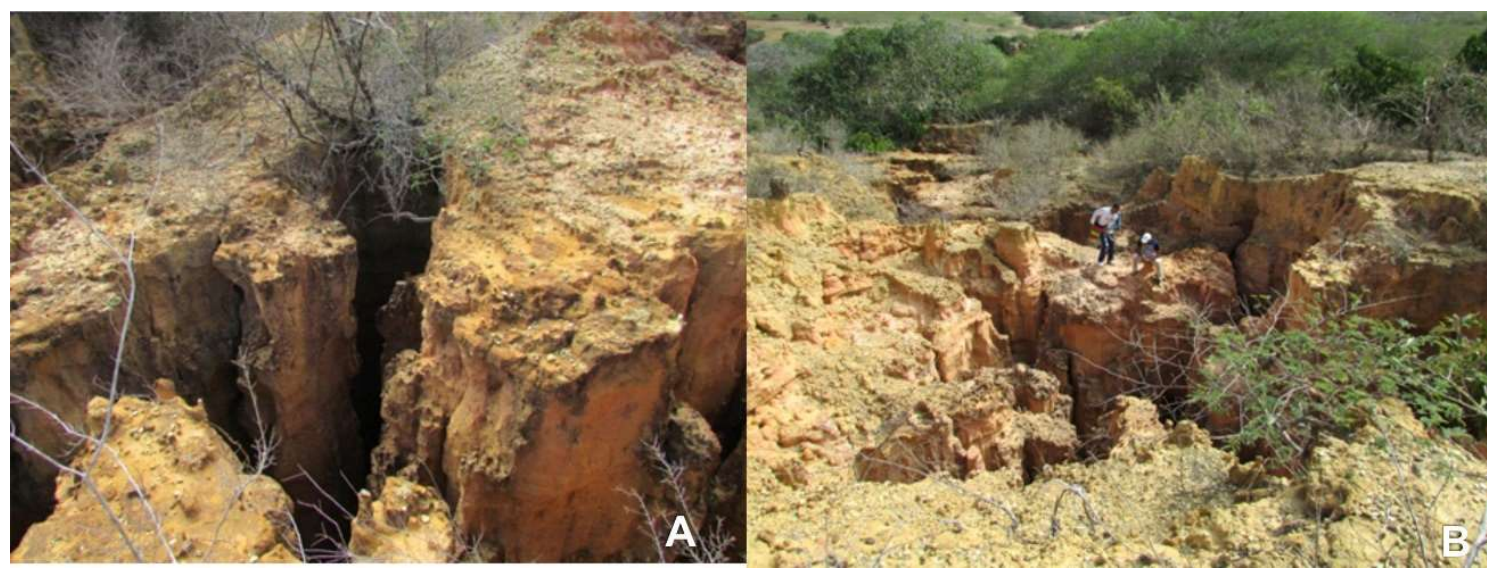

Fonte: Acervo particular dos autores, 2018.

Ainda no terço inferior da voçoroca, observa-se que a vertente apresenta uma inclinação suave, com variação entre de $0 \%$ a $3 \%$ favorecendo o desenvolvimento de cones de dejeção do canal principal, além disso, identifica-se na área, a instalação da comunidade Quilombola "Tucano de Fora", bem como propriedades privadas que se utilizam da área aplainada, com considerável quantidade de sedimentos depositados ainda em processo de consolidação, para a construção de casas e pequenas atividades agrícolas (figura 7). 
Figura 7 - Área de deposição no terço inferior da voçoroca, utilizada para agricultura de pequeno porte pelo morador da comunidade quilombola "Tucano de Fora".

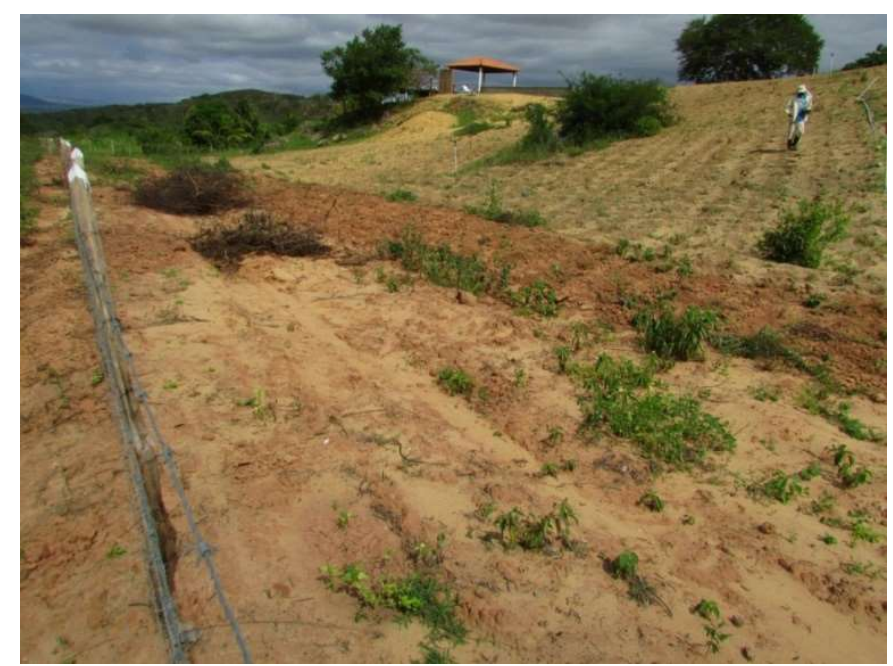

Fonte: Acervo particular dos autores, 2018.

A estrutura interna da voçoroca apresenta elementos diferenciados em toda extensão da feição erosiva. O primeiro elemento é o desnível altimétrico interno. Dessa forma, em atividade de campo, observou-se que, no interior dessa voçoroca, com dimensões areais de 13,37 km², há uma variação considerável dos níveis de entalhamento vertical (sub-aberturas internas), formando assim, ravinas de $32 \mathrm{~cm}$ de profundidade, além de ocorrer incisões de maiores proporções, variando de 06 até 19 metros de profundidade (figuras $8 \mathrm{a} / \mathrm{b} / \mathrm{c}$ ).

Figura 8 - a) Ravina de $32 \mathrm{~cm}$ de profundidade por $19 \mathrm{~cm}$ de largura no canal secundário 02 ; b) Incisão vertical de 6,12 metros no canal secundário 02; c) Incisão vertical de 18,37 metros de profundidade no

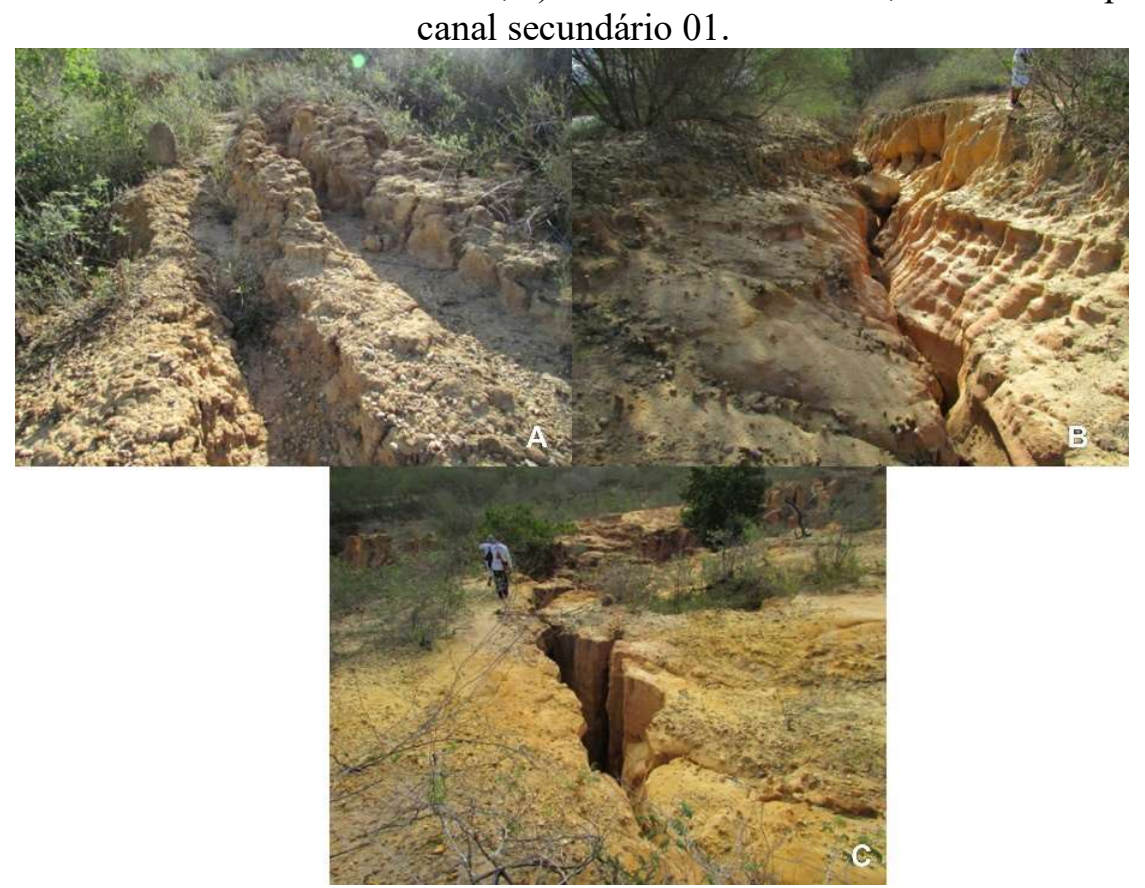

Fonte: Acervo particular dos autores, 2018. 
Nessa perspectiva, a justificativa pertinente para a apresentação de feições erosivas diferenciadas no interior da voçoroca, de acordo com Bigarella et al. (2007) e Guerra (2011), é a forma irregular do escoamento superficial concentrado devido ao padrão pluviométrico regional que concentra precipitações torrenciais em determinados meses do ano, típico do clima semiárido brasileiro, induzindo assim, a abertura de canais profundos e, nos meses de menor precipitação, a abertura de pequenos sulcos.

Considerando também as proposições de Bertoni e Lombardi Neto (2010), outro fator está na variabilidade do gradiente textural da cobertura pedológica, tendo em vista que, apesar das bases apresentarem duas unidades de solos, é perceptível a existência de uma variação significativa do teor de matéria orgânica, organização dos poros e da distribuição de areia e argila ao longo da vertente e sobre uma mesma classe pedológica. Assim, observando esses dois elementos, associando ocorrência torrenciais com solos de maior susceptibilidade e declividade superiores a $30 \%$, tem-se o início do processo erosivo.

A variação no entalhamento da voçoroca nada mais é do que uma resposta ao grau de coesão do material geológico, que impõe, naturalmente, resistência quando o fluxo de água pluvial percorre essas áreas promovendo a erosão por escoamento superficial concentrado e/ou difuso. Entre as aberturas de maiores proporções, observa-se a resistência do material sedimentar em blocos rochosos, dando às feições, em determinadas situações, aspecto de morfologia bifurcada na encosta dos canais secundários 01 e 02 (figura 9). Esses blocos no interior das incisões erosivas, permanecem em constante desgaste físico-químico no decorrer do tempo, tanto pela ação eólica, como pluvial, principalmente, nos períodos de chuvas torrenciais.

Figura 9 - Incisão vertical de 13,21 metros com a presença de blocos rochosos no seu interior proporcionando a bifurcação da estrutura erosiva.

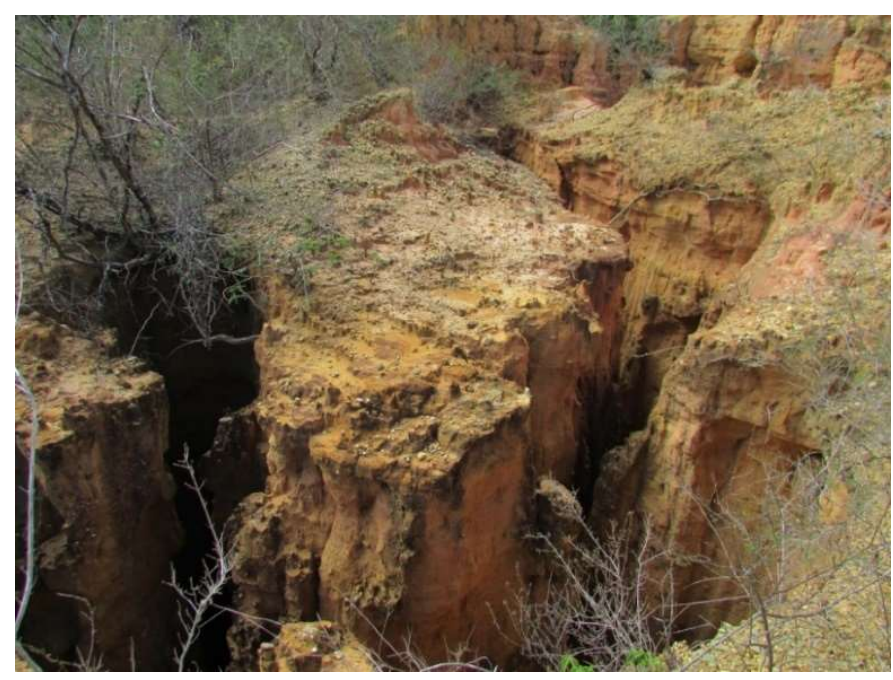

Fonte: Acervo particular dos autores, 2018. 
O canal principal apresenta uma incisão de maior alargamento, porém, com menor profundidade, tendo em vista que os canais secundários depositaram em seu interior, toda a sedimentação que foi retirada durante a ação das chuvas (figura 10a). Também é interessante observar que o canal principal, por conta de seu alargamento, durante décadas, serviu de estrada vicinal que ligava as cidades de Tucano à Ribeira do Pombal, fato esse, que contribuiu, ainda mais para a manifestação da erosão e alargamento do canal devido à contínua passagem de automóveis e animais (figura 10b).

Figura 10 - a) abertura do canal principal da voçoroca, com uma subabertura horizontal interna de 21,57 metros. b) Área do canal principal da voçoroca utilizado como estrada vicinal de ligação dos municípios de Tucano à Ribeira do Pombal, atualmente com aberturas de ravinamento pela presença da ação humana.

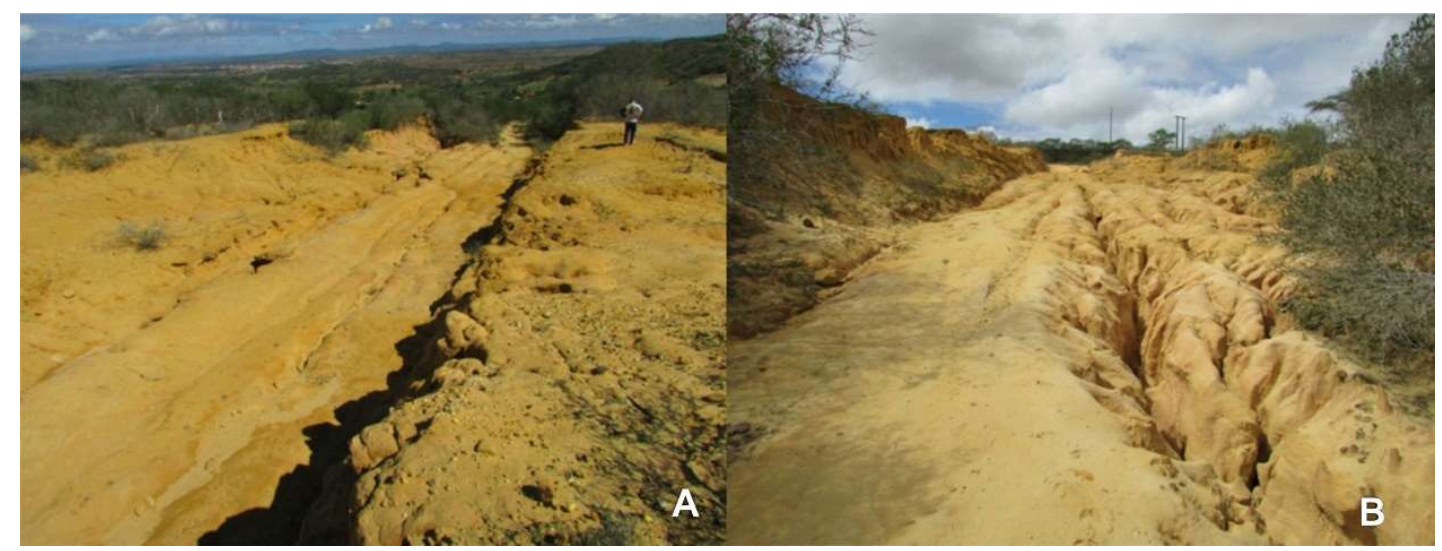

Fonte: Acervo particular dos autores, 2018.

Os pedestais existentes nos canais secundários 01 e 02 ocupam de forma generalizada a área da voçoroca. Sob esse viés, pressupondo as características de Bertoni e Lombardi Neto (2010), os pedestais originam-se pelos processos de salpicamento associados à erosão superficial difusa laminar, nos quais os materiais granulares mais resistentes acabam formando os pedestais residuais (figura 11). 
Figura 11 - Formação da feição residual interna de pedestal no canal secundário 01.

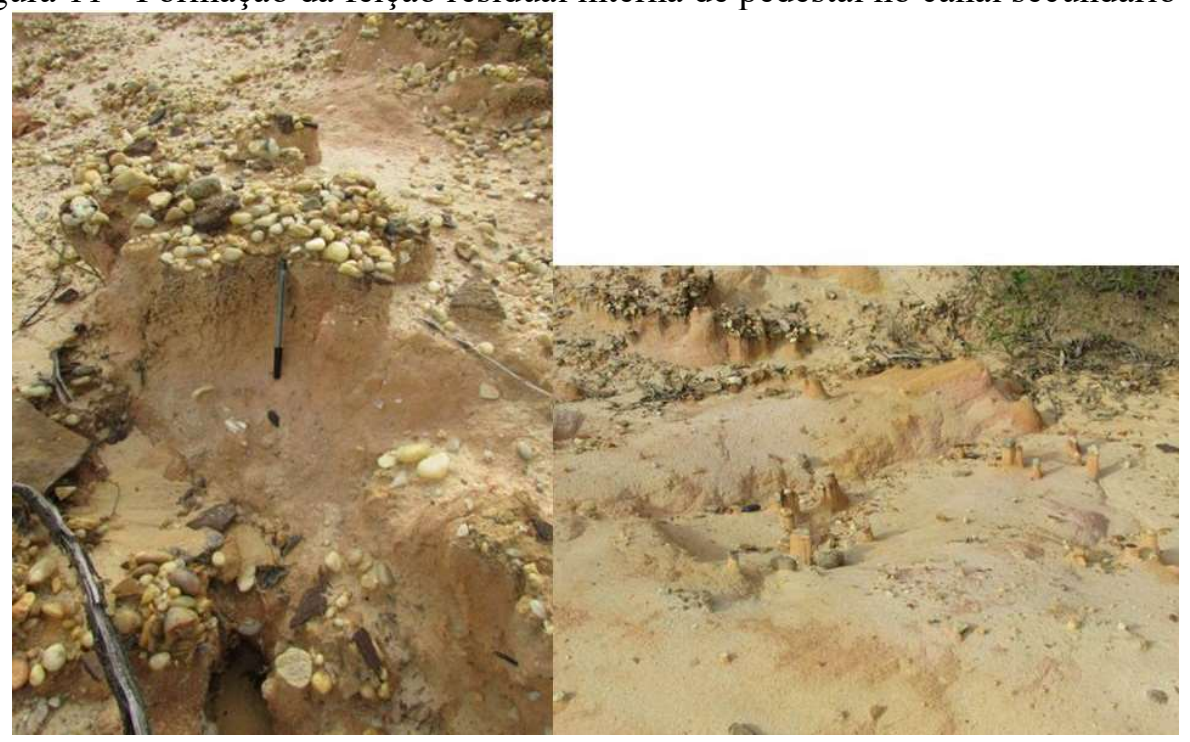

Fonte: Acervo particular dos autores, 2018

Associado as formações de pedestais, identificou-se a feição de escamamentos que, com base em Vieira (2008), é gerado pelo acúmulo do material sedimentar fino, sendo esse, recoberto por camadas mais grosseiras de sedimentos em um único perfil. As formações de marmitas residuais estão associadas aos locais de desníveis altimétricos, nas quais ocorre o fluxo de água por turbilhonamento, afetando tanto as paredes das cicatrizes erosivas, quanto o fundo da voçoroca. Nesse sentido, as marmitas residuais, geralmente são evidenciadas na área de cabeceira da voçoroca, associado a processos de ravinamentos conforme visualizadas no canal secundário 02 (figura 12).

Figura 12 - Formação de marmitas residuais paralelos à formação de ravinas difusas na parede do canal secundário 02.

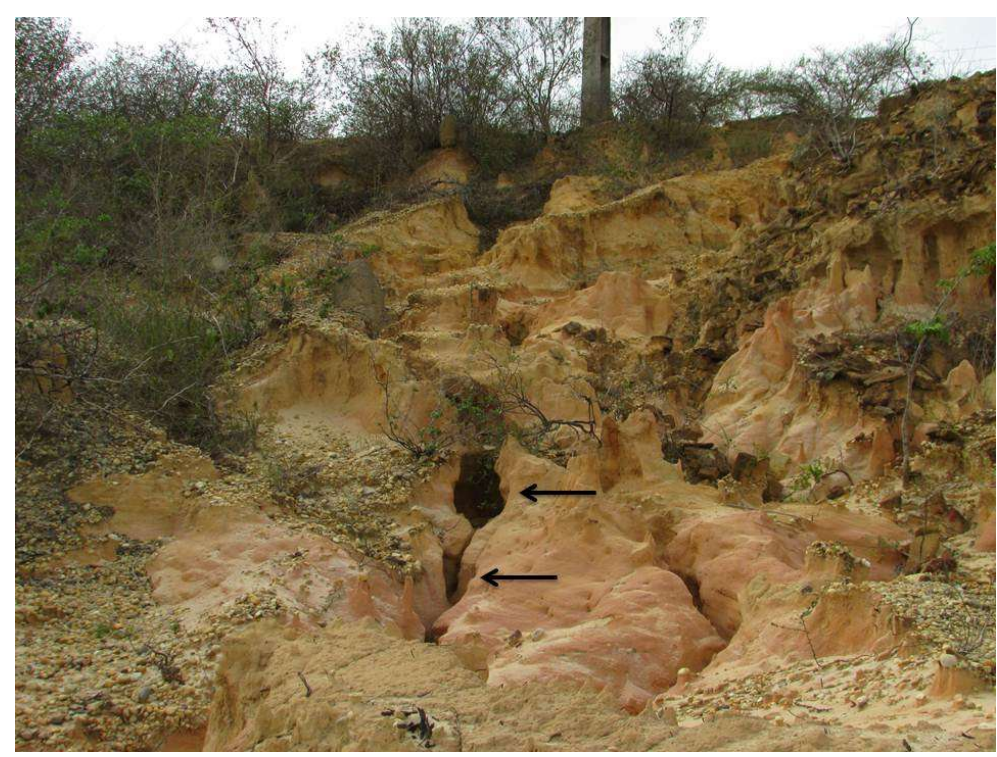

Fonte: Acervo particular dos autores, 2018. 
A morfologia de costelas se manifesta nas paredes da cabeceira da voçoroca evidenciando a diferença no grau de resistência do material pedológico ou geológico da área. A costela forma aberturas horizontais por desagregação mecânica do material em oposição com camadas resistentes à erosão que ali permanecem (figura 13). Num processo de desagregação mecânica mais intensa, a costela poderá evoluir para marmitas residuais ou alcovas de regressão.

Figura 13 - Morfologia interna de costelas na cabeceira do canal secundário 02, da V1, com a presença do material resistente (Costelas $=\mathrm{C}$, setas brancas) e o material erodido (pequenas depressões) menos resistente (Depressões $=\mathrm{D}$, setas pretas).

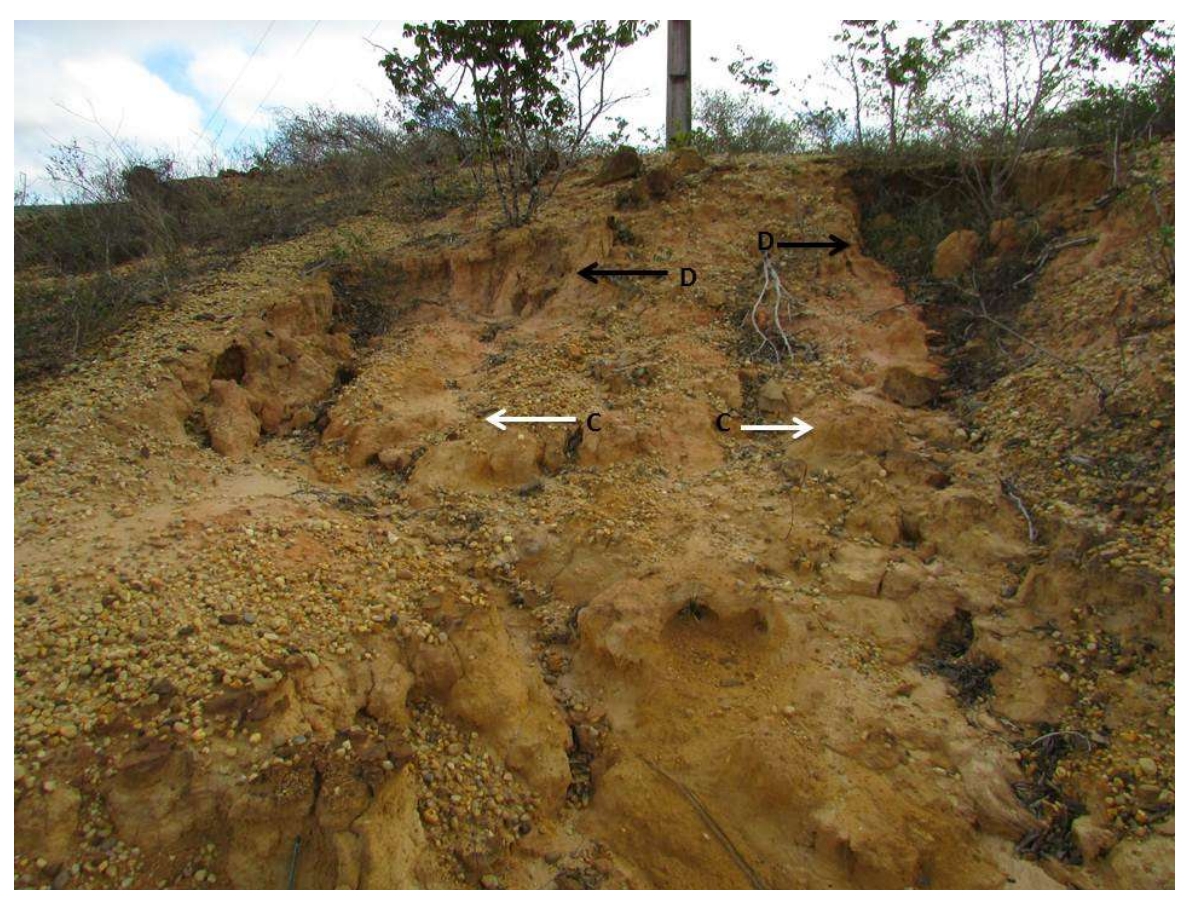

Fonte: Acervo particular dos autores, 2018.

\section{Posicionamento topográfico na vertente}

A morfometria possui relevância significativa porque avalia o grau quantitativo de aprofundamento da feição erosiva na vertente e o volume de solo que foi retirado e transportado para o terço inferior no desenvolvimento da voçoroca. Analisando a posição topográfica da erosão na vertente, observa-se que nos dias atuais, esta feição erosiva não possui ligação direta com a rede de drenagem do rio Itapicuru, a qual localiza-se ao sul do relevo local (figura 14). Por conta desse distanciamento da drenagem, afirma-se que a voçoroca é desconectada do sistema hidrográfico quando se posiciona entre os terços superior e médio da vertente. 
Figura 14 - Posicionamento tipológico da voçoroca na vertente. Tucano/BA, 2018.

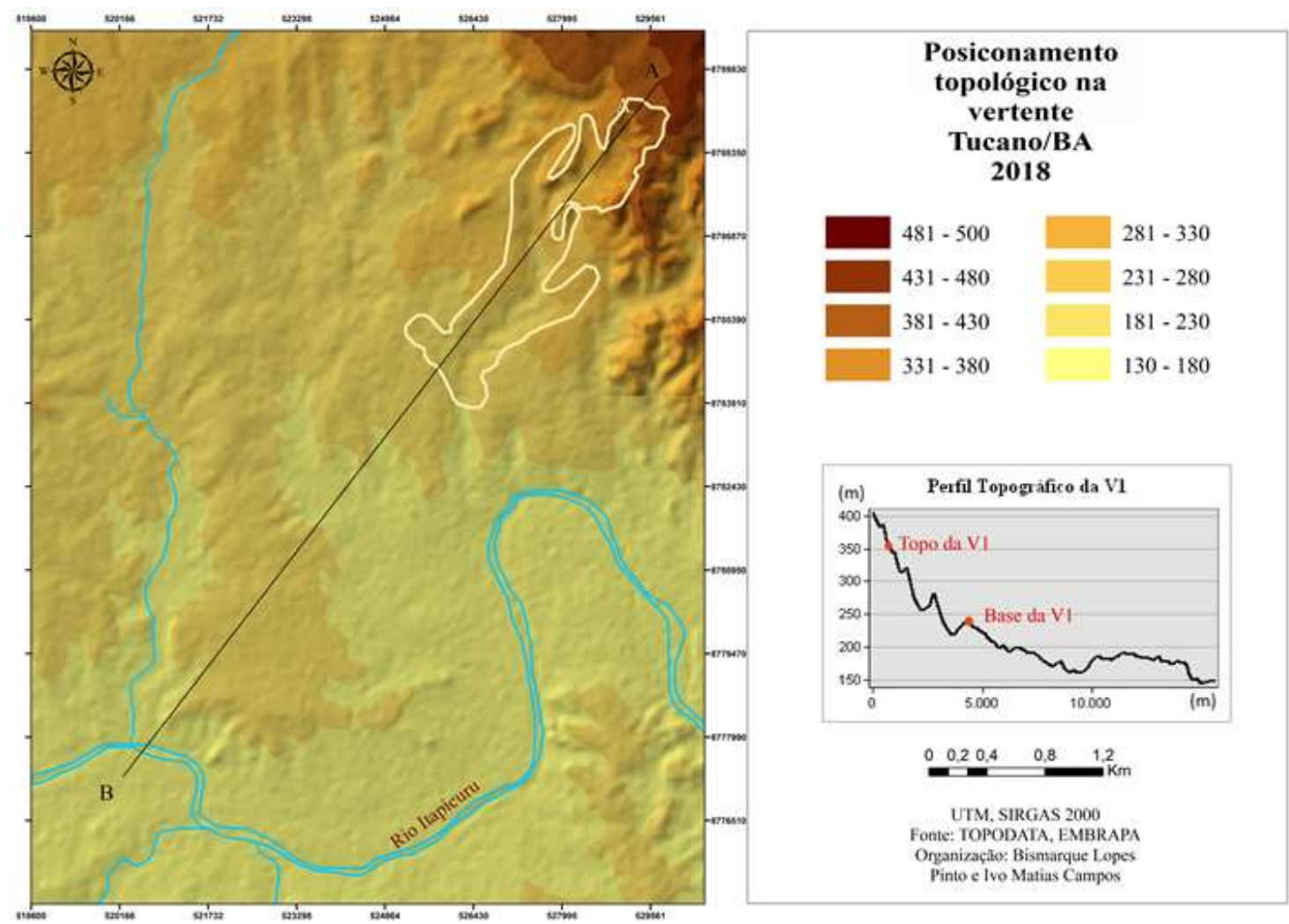

Fonte: Elaboração pelos autores, 2018.

Nesse âmbito, de acordo com a classificação de Oliveira (2009), as voçorocas desconectadas são consideradas iniciais, principalmente por conta de sua pequena extensão na vertente que ainda não estabelecem ligação com a rede de drenagem local. Contudo, vale destacar que possivelmente em condições climáticas pretéritas, em que a configuração atmosférica evidenciava um clima úmido, a voçoroca estabelecia uma condição integrada com o Rio Itapicuru, mas que, dada as condições de semiaridez e com as mudanças do nível de base da drenagem do Itapicuru, a voçoroca desligou-se da drenagem, deixando na paisagem, extensos plainos de acumulação que formam os pediplanos intermontano.

Observa-se no perfil topográfico que o processo de incisão na vertente começa na queda abrupta da altimetria, evidenciada no topo da voçoroca. Dessa forma, a variação altimétrica dessa voçoroca na vertente é de 150 metros, do topo até a base, com desenvolvimento de banco de sedimentos. 


\section{CONSIDERAÇÕES FINAIS}

Abordar o tema voçoroca e erosão dos solos é de fundamental importância para se compreender como esse fenômeno influencia na evolução das paisagens. A escolha do lócus desta pesquisa emergiu a partir da indagação inicial do desconhecido, diante do panorama erosivo bastante expressivo existente no espaço rural do município de Tucano/BA, sem que, até os dias atuais, tivesse merecido estudos empíricos para uma análise explicativa da evolução da erosão pela tamanha grandeza registrada na paisagem local ao longo do tempo geológico.

Então, dadas as grandes dimensões da área, afirma-se que o sistema de voçorocamento predominante no espaço rural do município de Tucano tem sua gênese associada à interferência conjunta dos processos naturais na evolução do relevo tabuliforme local, mesmo porque as atividades econômicas desenvolvidas no perímetro de domínio das cicatrizes erosivas, pela sua expressividade no terreno, limitam-se na criação de gado, de maneira aleatória, além da agricultura familiar esporádica que não demandam um uso intensivo do solo capaz de repercutir na evolução rápida do relevo local, a não ser de forma muito secundária, com resultados quase imperceptíveis.

Os questionamentos iniciais norteadores da pesquisa foram respondidos com os resultados empíricos a partir da constatação in loco das feições morfológicas internas e externas comprovando processos evolutivos das voçorocas engendrados pela ação do escoamento superficial das águas das chuvas torrenciais impulsionando energeticamente o fluxo de matéria das voçorocas. Tal aspecto reflete na formação de dutos, de marmitas e costelas, além da disseminação de sulcos e ravinas que entalham cada vez mais a vertente retirando sedimentos e, com isso, aumentando a perda de solo.

Neste sentido, os parâmetros aqui pré-estabelecidos, elencados na metodologia, prezou pelo cuidado na classificação das morfologias externas e internas, com o rigor científico de comprovar os fenômenos reconhecidos em campo e pelo ambiente SIG nas imagens captadas e georreferenciadas da área. Assim, o parâmetro adotado para a perda de solo, apesar de classificar as feições erosivas de menores dimensões, verificou-se que elas acabam ganhando destaque na paisagem morfológica, pelo fato de apresentarem significativas crateras erosivas com os mais variáveis níveis de profundidade e alargamentos no perímetro delimitado para esse estudo.

Portanto, é interessante observar que a voçoroca investigada ainda necessita de um tempo geológico maior para evoluir, dadas as condições climáticas predominantes no ambiente, uma 
vez que ainda se limita ao terço superior e médio das vertentes sem expansões atuais para o terço inferior, de modo que seja desconectada com rede de drenagem existente na área por conta do distanciamento.

Dessa forma, o aparecimento de pedestais na voçoroca, evidencia a atuação de sucessivos processos erosivos influenciados pelo escoamento superficial difuso. Finalmente, os resultados aqui apresentados servem de base para a implementação de uma política de planejamento ambiental, até mesmo pelo pioneirismo da investigação, já que a área sempre foi vista como lugar inútil e de pouco interesse sob o ponto de vista da gestão municipal local. Assim, pelo alto grau de degradação a que chegou a área do perímetro das voçorocas urge uma tomada de medidas que visem à preservação do ambiente.

\section{AGRADECIMENTOS}

O presente trabalho foi realizado com apoio financeiro da Coordenação de Aperfeiçoamento de Pessoal de Nível Superior - Brasil (CAPES) - Código de Financiamento 001 .

\section{REFERÊNCIAS}

BERTALANFFY, L. V. Teoria Geral dos Sistemas. Petrópolis: Editora Vozes, 1977.

BERTONI, J.; LOMBARDI NETO, F. Conservação do solo. São Paulo: Editora Ícone, 2010.

BIGARELLA, J.J.; MAZUCHOWSKI, J.Z. Visão integrada da problemática da erosão. In: III Simpósio Nacional de Controle de Erosão. Maringá, 1985.

BRAUN, W. A. G. Contribuição ao estudo da erosão no Brasil e seu controle. Revista Brasileira de Geografia, Rio de Janeiro, v. 02, n. 4, p. 591-642, 1961.

CARVAlHO, J. C. de; SAlES, M. M; MORTARI, D; FÁZIO, J. A; MOTTA, N. O. da; FRANCISCO, R. A. Processos erosivos. In: CARVALHO, J. C. de; SALES, M. M; SOUZA, M. N. de; MELO, M. T. da S (orgs.). Processos erosivos no centro-oeste brasileiro. Brasília: FINATEC, 2006.

GUERRA, A. J. T. Processos erosivos nas encostas. In: GUERRA, A. J. T; CUNHA, S. B. da (orgs.). Geomorfologia: uma atualização de bases e conceitos. Rio de Janeiro: Bertrand Brasil, 2011.

LEPSCH, I. F. Formação e conservação do solo. São Paulo: Oficina de Textos, 2002. 
MELLO, C. L, 1997. Sedimentação e tectônica cenozóica no médio vale do rio doce (MG, sudeste do Brasil) e sua implicação na evolução de um sistema de lagos. Tese de Doutorado. Universidade de São Paulo, Faculdade de Filosofia, Letras e Ciências Humanas, São Paulo, SP.

MOURA, J. R. da S. Geomorfologia do Quaternário. In: GUERRA, A. J. T.; CUNHA, S. B. (orgs.). Geomorfologia: Uma atualização de bases e conceitos. Rio de Janeiro: Bertrand Brasil, 1994.

OLIVEIRA, M. A. T. de. Processos erosivos e preservação de áreas de risco de erosão por voçorocas. In: GUERRA, A. J. T; SILVA, A. S.; BOTELHO, R. G. M. (orgs.). Erosão e conservação dos solos: conceitos, temas e aplicações. Rio de Janeiro: Bertrand Brasil, 2009.

ROSS, J. L. S. Geomorfologia: ambiente e planejamento. São Paulo: Editora Contexto, 2010.

ROSS, J. L. S. O registro cartográfico dos fatos geomórficos e a questão da taxonomia do relevo. Revista do Departamento de Geografia, Rio de Janeiro, v. 20, n. 06, p. 17-30, 1992.

RUHE, R.V. Geomorphology: Geomorphic processes and surficial geology. Boston: Houghton Mifflin, 1975.

VIEIRA, A. F. G, 2008. Desenvolvimento e distribuição de voçorocas em Manaus (AM): Principais fatores controladores e impactos urbano-ambientais. Tese de Doutorado. Universidade Federal de Santa Catarina, Programa de Pós-Graduação em Geografia, Florianópolis, SC. 